\title{
Structural assessment of a RC Bridge over Sororó river along the Carajás railway
}

\section{Avaliação estrutural da ponte sobre o rio Sororó na ferrovia Carajás}
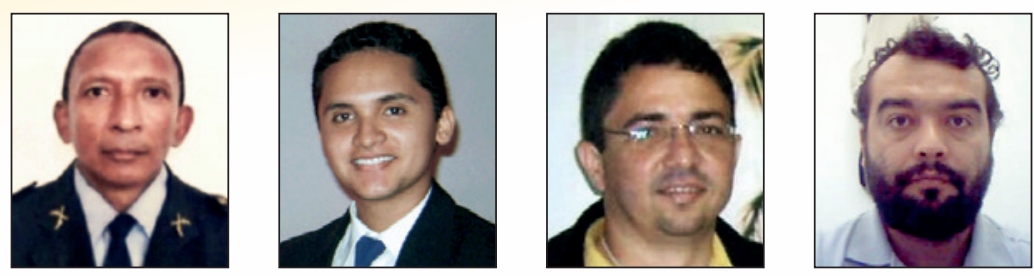

J. C. L. MATOS cristinomatos@globomail.com

V. H. L. BRANCO a brancovh@yahoo.com.br

A. N. MACÊDO anmacedo@ufpa.br

D. R. C. OLIVEIRA a denio@ufpa.br

\begin{abstract}
The Carajás railway is operated by Vale SA and is used to transport the Brazilian production of iron ore mine located in the state of Pará until Itaqui harbor in Maranhão state. With $892 \mathrm{~km}$ in length, the railway will be doubled due to the prospect of increased production, which requires verification of the structures of bridges to ensure safety under loading up to $23 \%$ larger. The railway bridge in reinforced concrete has five hyperstatic spans with $25 \mathrm{~m}$ long and was built over Sororó river in the southeast of Pará. To better evaluate its structural performance under current loadings, several structural elements were monitored with strain gages and the concrete was characterized by non-destructive and destructive testing on the structure. This information was used in a computer model to estimate the future structural behavior. The methodology was satisfactory as the estimated structural performance for future loadings, meeting the recommendations of the Brazilian technical standards.
\end{abstract}

Keywords: concrete structures, bridge, railroad.

\section{Resumo}

A ferrovia Carajás é operada pela Vale SA e é utilizada para transportar a produção brasileira de minério de ferro da mina localizada no estado do Pará até o porto de Itaqui no estado do Maranhão. Com $892 \mathrm{~km}$ de comprimento, a ferrovia será duplicada devido à perspectiva de aumento da produção, o que requer a verificação das estruturas de suas pontes visando garantir a segurança sob carregamento até $23 \%$ maior que o atual. A ponte ferroviária em concreto armado apresenta cinco vãos hiperestáticos com $25 \mathrm{~m}$ de comprimento cada e foi construída sobre o rio Sororó, na região sudeste do Estado do Pará. Para melhor avaliar seu desempenho estrutural sob carregamentos atuais, diversos elementos estruturais foram monitorados com extensômetros elétricos de resistência e o concreto foi caracterizado através de ensaios não destrutivos e destrutivos na estrutura. Estas informações foram empregadas em um modelo computacional para auxiliar na estimativa do comportamento estrutural futuro. A metodologia mostrou-se satisfatória, assim como o desempenho estimado da estrutura para os futuros carregamentos, atendendo às recomendações das normas técnicas brasileiras.

Palavras-chave: estruturas de concreto, ponte ferroviária, estrada de ferro.

Universidade Federal do Pará, Belém, Pará, Brasil. 


\section{Introduction}

The Carajas railroad is a railway operated by Brazilian multinational Vale SA, which is one of the major mining companies in the world and the largest producer of iron ore. Most of the bridges along Carajas railway are reinforced concrete structures with stringers spaced from $2.0 \mathrm{~m}$ to $3.0 \mathrm{~m}$ in order to enable the construction of concrete decks with thickness of $200 \mathrm{~mm}$ to $250 \mathrm{~mm}$ [1]. These bridges require strategic maintenance programs since they are located in an aggressive environmental and also because the traffic demands are frequently increasing. Both factors may contribute to the progressive deterioration of their structure [2]. The diagnosis of the actual conditions of existing bridges is fundamental to establish programs for its rational maintenance in order to choose the best structural rehabilitation method once that the interruption of traffic in railways may lead to great economic losses [3].

This paper presents a methodology used to evaluate the structural integrity of reinforced concrete bridges along the Carajas railway. It also presents results of "in situ" investigations and computational analysis carried for a bridge over the river Sororo, geographically located in the points $-5.440702^{\circ}$ (lat.) and $-49.134550^{\circ}$ (long.). To evaluate its structural integrity a series of field activities were performed: rebars scan to check if the reinforcements were placed as specified in the original design; hardness tests of concrete in order to define its actual compressive strength; extraction of concrete samples from structure elements to perform laboratory destructive tests for the determination of the concrete mechanical properties; and monitoring of structural elements with strain gauges to check its structural response under actual live loads and to estimate the fatigue lifetime. A linear-elastic finite element analyses was carried to verify the safety of the bridge's original design and to evaluate if its performance under future loads will be within the limits imposed by the Brazilian design codes.

\subsection{General characteristics of the bridges and train-type}

The bridge was constructed in the 1990s with cast-in-place reinforced concrete. Its superstructure consists of five (05) hyper static spans, each one with $25 \mathrm{~m}$ length, with a total length of $125 \mathrm{~m}$ and with vertical inclination of $0.4 \%$. Its cross section has a total width of $5.8 \mathrm{~m}$ and supports the railroad, gravel ballast, lateral channels for drainage and cables, metallic guardrails with shelters at each $10 \mathrm{~m}$, and a short cantilever slab to support lampposts. The substructure consists of four (04) cast-in-place reinforced concrete central piers formed by rectangular columns supported on caps over belled circular caissons with shaft of $1.4 \mathrm{~m}$ and bell with $3.2 \mathrm{~m}$, as shown in Figure 1. The bridge's abutments have width of $14.3 \mathrm{~m}$ and are formed by four longitudinal walls and two transverse walls. A movement joint is placed over column P3. The cross section of the bridge's deck is of the type beam and slab formed by two rectangular ribs of constant height monolithically linked to the slabs and to reinforced concrete short transversal beams. Figure 2 presents photos and general sketches of the superstructure and substructure of the bridge. The substructure consists of four rectangular columns with cross-section measuring $(1.0 \mathrm{~m} \times 2.8 \mathrm{~m})$ and $5.0 \mathrm{~m}$ height, supported on caissons with circular shaft and base with diameters of $1.4 \mathrm{~m}$ and $3.2 \mathrm{~m}$, respectively. Each abutment of the bridge has four transverse and two longitudinal walls supported over a block on eight caissons. An expansion joint was positioned on the column P3.

\section{Figure 1 - Railway bridge on the river Sororo}
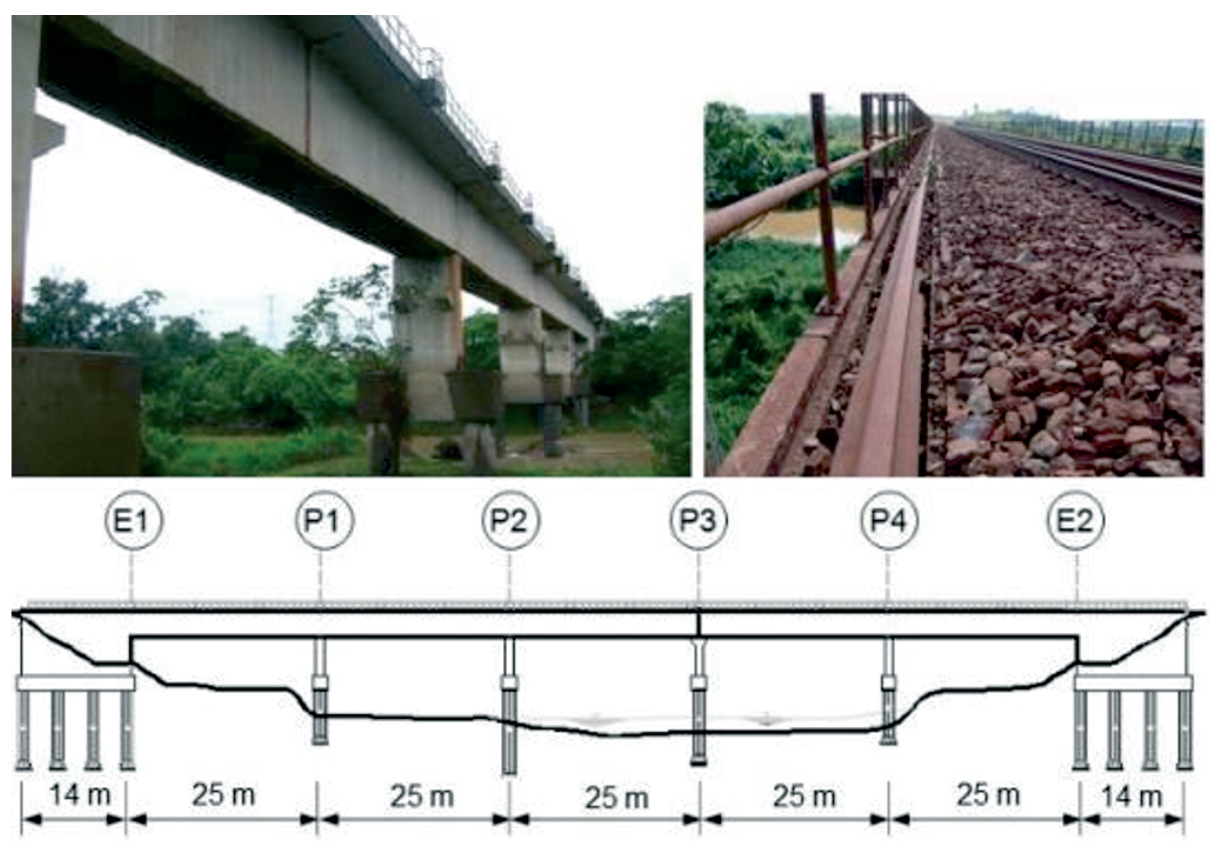
Figure 2 - Structural elements' dimensions (m)
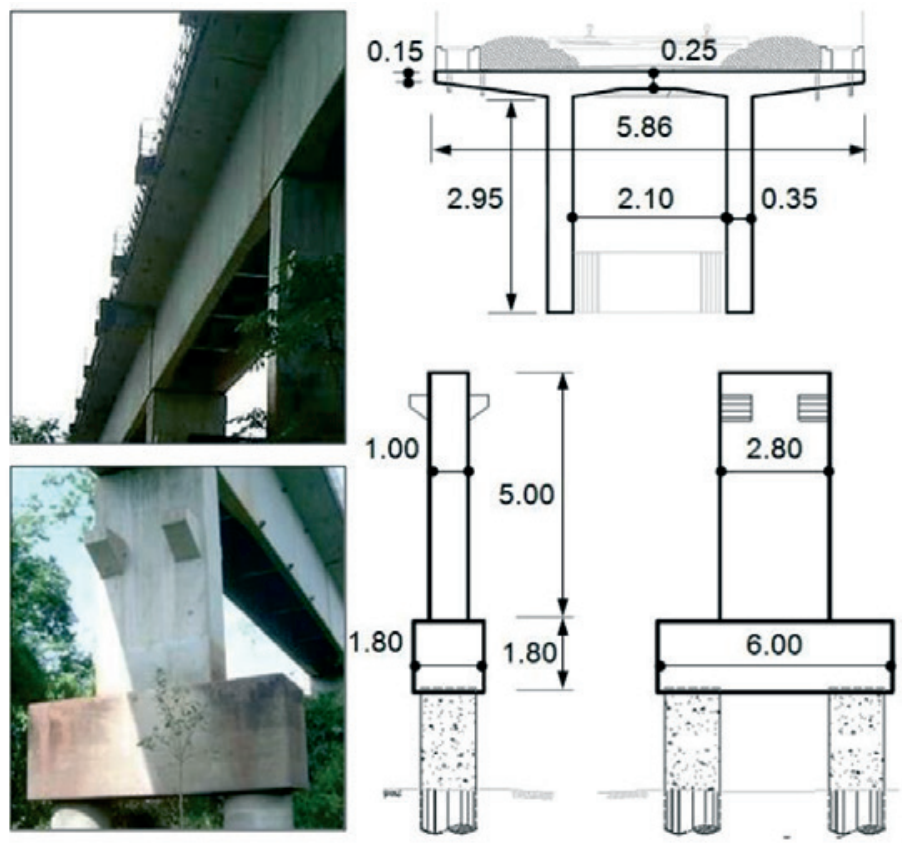

The Carajas railroad is used to transport iron ore from Carajas city (Para state) to Itaqui harbor (Maranhao state). Actually, a locomotive type DASH9 and wagons type GDT are used to transport the iron ore. The DASH9 locomotive weighs $1,800 \mathrm{kN}$, while the loaded GDT wagon weighs $325 \mathrm{kN} / \mathrm{axis}$ and $53 \mathrm{kN} /$ axis when unloaded. The actual train used is formed by 2 locomotives +110 wagons +1 locomotive +110 wagons +1 locomotive +110 wagons .
Figure 3 shows the dimensions of these locomotives and wagons.

\section{Material and methodology}

\subsection{Visual inspection}

Cracks in the outer faces of the stringers were observed during

Figure 3 - DASH 9 locomotive and GDT wagon (m)

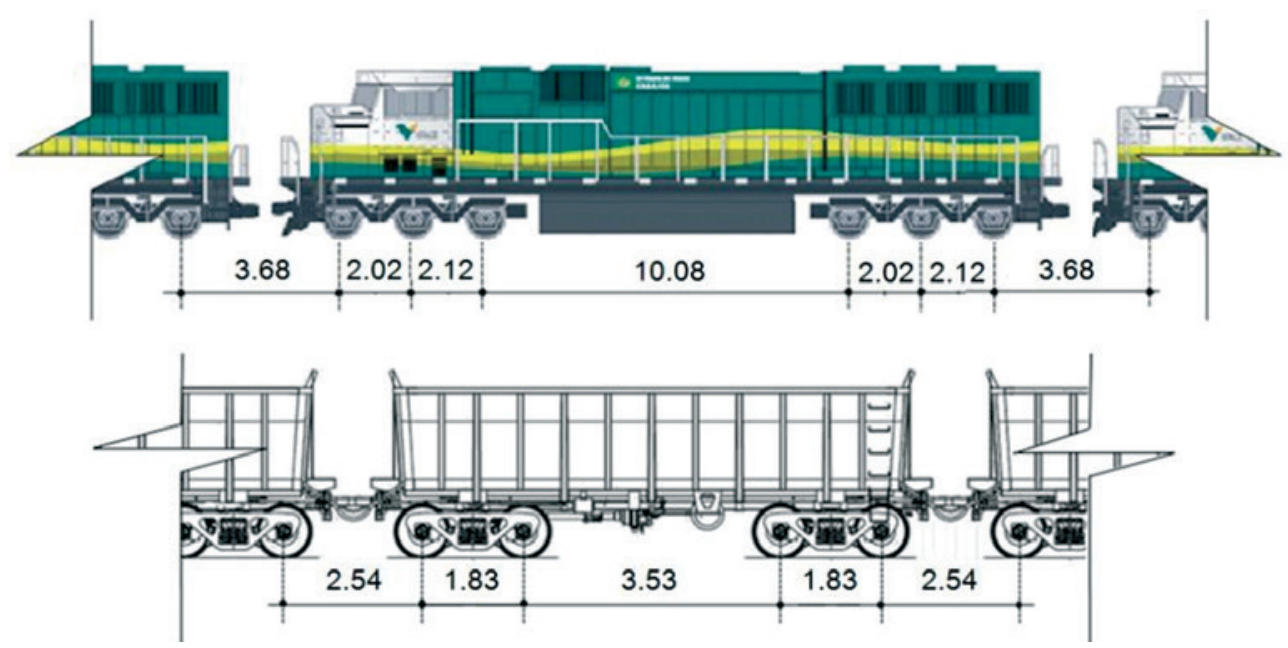


the visual inspection of the bridge. These cracks were vertical in the middle of the span and slightly inclined in the sections near the supports, but distant from the bottom surface. These cracks were more visible in the outer faces of the stringers, with only a few observed in the inner faces. Regardless of the nature of cracking process (bending, shrinkage, etc.) they may induce corrosion damage to steel reinforcement in future [4]. In the surface of transversal beams cracks with efflorescence and water percolation were also observed, but no evident signs of significant corrosion on rebars were observed. Yet, these damages may also reduce the lifetime of the bridge as highlighted in technical literature [5].

\subsection{Non-destructive tests}

Non-destructive testing (NDT) enclose a variety of techniques used to define properties of a material without causing damages. Aiming to determinate the actual compressive strength of concrete of the bridge, Schmidt/rebound hammer tests were carried, which evaluate the surface hardness of concrete and through correlations with calibrated results allow the determination of the compressive strength of concrete. Before performing the hardness tests, the structural elements were scanned in order to properly determinate the position of its rebars, in an attempt to avoid its influence in tests results. The observed spacing between the bars $1.5 \mathrm{~m}$ above the base of each column ranged from 100 to $50 \mathrm{~mm}$. In addition to the position of the bars, were also determined its direction and diameter and the thickness of the concrete cover, which was in general equal to $50 \mathrm{~mm}$. The hardness tests were performed on column P2, foundation caps, deck slabs, stringers and abutments. The concrete strength was defined based on the effective average rebound hammer index (Table 1) for each analyzed area (150 $\mathrm{mm} \times 150 \mathrm{~mm}$ with 9 impact points) as recommended by Brazilian codes [6].

\subsection{Destructive tests}

Destructive tests (DT) are those carried out until the specimen's failure. These tests require damaging parts of the structure in order to obtain samples to perform direct tests in a laboratory. Only two

\begin{tabular}{|ccc|}
\hline $\begin{array}{c}\text { Table 1 - Average results from rebound } \\
\text { hammer tests on structural elements }\end{array}$ \\
\hline Structural element & Area & $\mathbf{f}_{\mathrm{c}}(\mathrm{MPa})$ \\
\hline Abutment 01 & 1 & 60.8 \\
\hline Abutment 01 & 2 & 57.1 \\
\hline Deck slab & 1 & 45.8 \\
\hline Deck slab & 2 & 43.6 \\
\hline Block B3 & 1 & 46.0 \\
Block B3 & 2 & 46.0 \\
\hline Column P2 & 1 & 57.8 \\
Column P2 & 2 & 56.6 \\
\hline
\end{tabular}

(02) types of destructive tests were carried out during the bridge's structural evaluation. One of these tests was carried in order to check the carbonation degree of the concrete cover. The other test involved the extraction of concrete samples to perform compressive and splitting tests in the lab. The carbonation tests carried consisted of removing selected parts of the concrete cover from the stringers and from the deck slabs. After that, concrete alkalinity was checked by using phenolphthalein. Tests showed that concrete alkalinity was adequate as shown in Figure 4 (left).

Many factors may influence results of surface hardness tests on concrete such as surface roughness, humidity condition and positioning of the equipment. Due to these reasons, it was decided to evaluate the actual compressive strength of concrete by both surface hardness tests and direct axial compression tests on samples extracted from the structure using a rotating diamond crown [7], as shown in Figure 4 (center). Eight samples were extracted: two from abutment E1; two from bridge-deck slabs; two from column P2; and two from foundation B3. The samples were cylindrical with $100 \mathrm{~mm}$ of diameter and $200 \mathrm{~mm}$ length and the drilling points were carefully selected in order to avoid steel bars. They were tested to axial compression for the determination of

\section{Figure 4 - Experimental procedures}
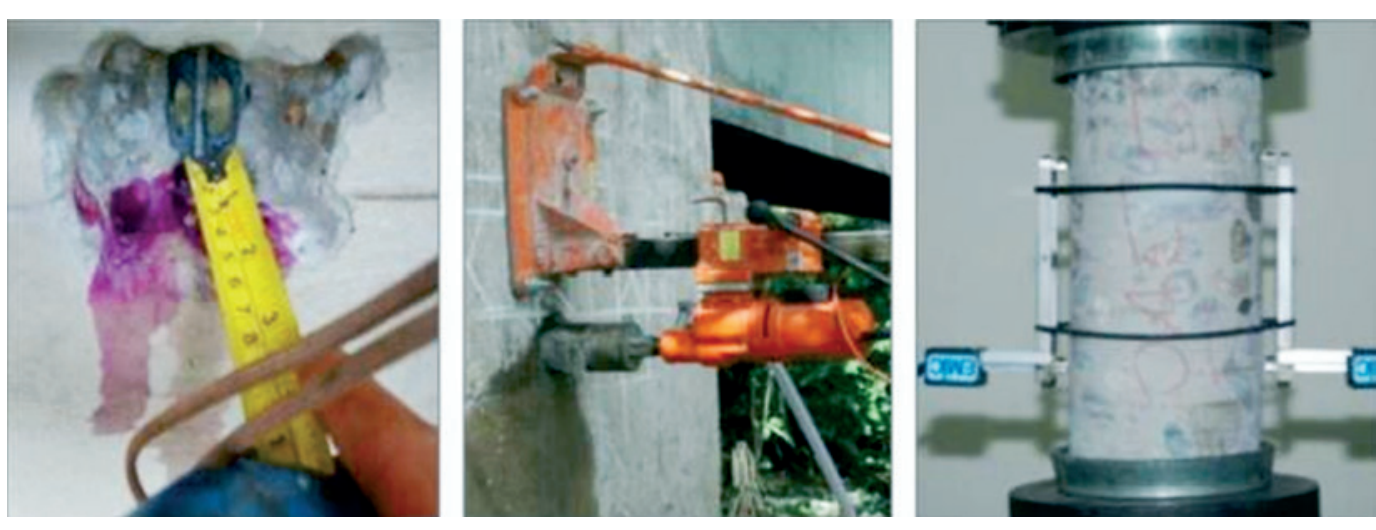


\section{Table 2 - Concrete's mechanical properties}

\begin{tabular}{|ccccccc}
\hline Structural element & $\mathrm{f}_{\mathrm{c}}(\mathrm{MPa})$ & $\mathrm{f}_{\mathrm{c}^{\prime}}(\mathrm{MPa})$ & $\mathbf{E}_{\mathrm{c}, \text { NBR }}(\mathrm{GPa})$ & $\mathbf{E}_{\mathrm{c}, \text { EC2 }}(\mathrm{GPa})$ & $\mathrm{E}_{\mathrm{c}, \text { Exp. }}(\mathrm{GPa})$ \\
\hline Abutment 01 & 58.9 & 47.5 & 36.5 & 38.8 & 35.7 \\
\hline Deck slab & 44.7 & 42.6 & 31.8 & 35.4 & 33.8 \\
\hline Block B3 & 46.0 & 33.4 & 32.3 & 35.8 & 38.3 \\
\hline Column P2 & 57.2 & 54.6 & 36.0 & 38.5 & 39.9 \\
\hline
\end{tabular}

the compressive strength. During these tests strains were measured by two extensometers such as "clip-gage" (see Figure 4 right) for determination of the elasticity modulus of concrete, in accordance with recommendations adopted in Brazil [8].

\subsection{Experimental results}

As mentioned before, results from the alkalinity of concrete were satisfactory. Nevertheless, the compression strength results obtained by hammer tests were slightly lower than those determined through destructive tests performed on the extracted concrete samples, especially for the case of foundation B3. Yet, the percentage errors were considered acceptable once they are lower than those found in literature [9], i.e. for laboratory tests it is assumed a range of $\pm 15 \%$ to $20 \%$, with a well calibrated rebound hammer, and $\pm 25 \%$ for "in situ" tests. In general, the actual compressive strength of concrete is, on average, 2.7 times higher than the design strength of superstructure, which was only of $18.0 \mathrm{MPa}$.
Table 2 shows the compressive strength results for rebound hammer tests $\left(f_{c}\right)$ and for axial compression tests on extracted samples $\left(f_{c}^{\prime}\right)$ according to recommendations of NBR 5739 [10]. Table 2 also presents comparisons of experimental results for the modulus of elasticity of concrete obtained with destructive tests described with theoretical results obtained using recommendations of NBR 6118 [11] and EC2 [12]. In the case of theoretical estimates the compressive strength adopted were those obtained with rebound hammer tests. Figure 5 shows the characteristics curves from the elasticity modulus tests for testimonies T1 and T2 extracted from column P2.

\section{Computational model}

A liner-elastic finite element analysis of the bridge was performed in order to validate the experimental results obtained in the monitoring campaign. This analysis was carried using SAP $2000^{\circledR}$ with the dynamic load of the train considered with a simplified pseudo-

\section{Figure 5 - Characteristic curves of the elasticity modulus tests on concrete testimonies from column P2}
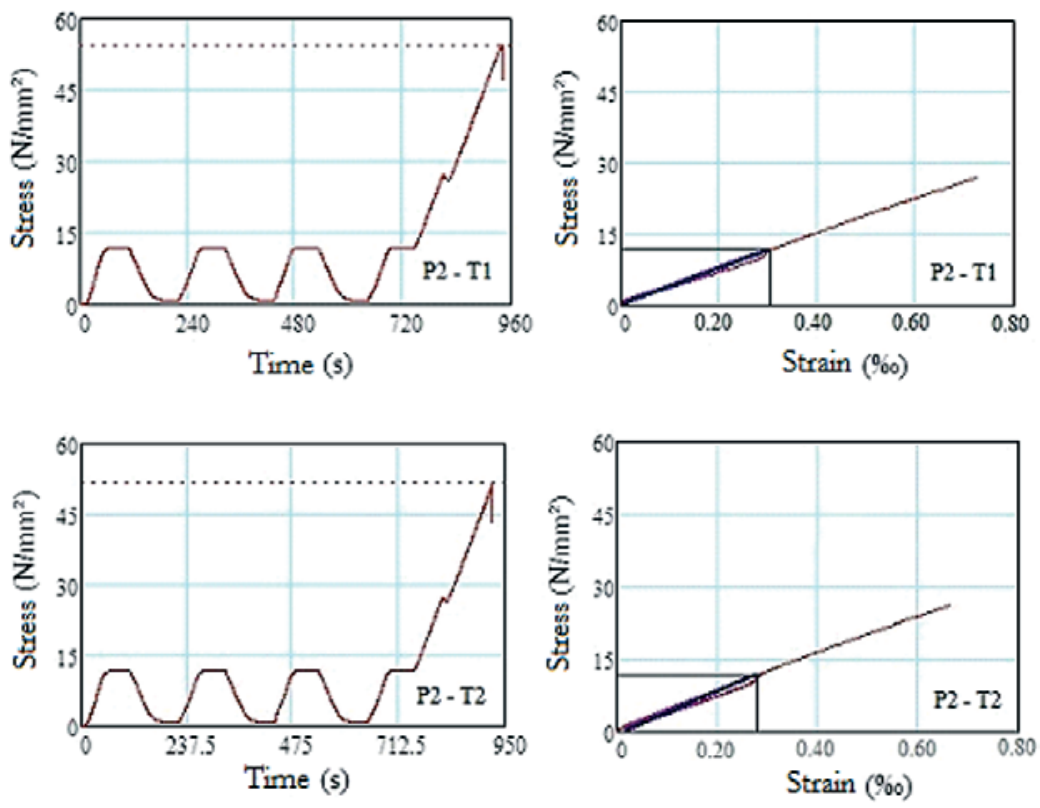


\section{Table 3 - Loads per axis of the train-type}

\begin{tabular}{cccc} 
Situation & DASH 9 locomotive & Loaded GDT wagon & Unloaded GDT wagon \\
\hline Current & $300 \mathrm{kN} /$ axis $(1.800 \mathrm{kN})$ & $325 \mathrm{kN} /$ axis $(1.300 \mathrm{kN})$ & $52.5 \mathrm{kN} /$ axis $(210 \mathrm{kN})$ \\
Future & $300 \mathrm{kN} /$ axis $(1.800 \mathrm{kN})$ & $400 \mathrm{kN} /$ axis $(1.600 \mathrm{kN})$ & $52.5 \mathrm{kN} /$ axis $(210 \mathrm{kN})$ \\
\hline
\end{tabular}

static analysis. Three computational models were developed using finite elements of the type beam, shell (4 nodes) and solid (8 nodes). The first was a simplified model in which the bridge's deck and pier were modeled using beam elements, with abutments and foundations considered with fixed constraints. In the second model the abutments and foundations were added to the first model using solid elements and with its ground supports considered as point springs. In the final model, the bridge's deck, composed by stringers and slabs, was modeled with shell elements. This final model was proved to be more realistic than the others and therefore was the model adopted in the computational analysis.

\subsection{Dead loads}

Depending on the specific weight of the materials and geometry of the structural elements, the computer program calculates the weight of the structure itself. In the case of ballast $(42.2 \mathrm{kN} / \mathrm{m})$, mortar on the deck slab $(5.5 \mathrm{kN} / \mathrm{m})$, channels $(6.5 \mathrm{kN} / \mathrm{m})$, railings $(0.3 \mathrm{kN} / \mathrm{m})$, rails, crossties and accessories $(7.9 \mathrm{kN} / \mathrm{m})$ was considered a loading of $62.4 \mathrm{kN} / \mathrm{m}$ distributed along the central longitudinal axis of the bridge.

\subsection{Live loads}

\subsubsection{Vertical actions}

The iron ore production will be increased with direct impact in the loading in Carajas railway and consequently in the bridges along. It is intended to maintain the same types of locomotives, wagons and composition used currently, but with increased load to be transported in each wagon. Table 3 shows the loads for the current and future compositions of locomotives and wagons. The Brazilian code for bridges' design, NBR 7187 [13], allows a simplified analysis of the dynamic effects caused by moving loads by using an impact coefficient that amplifies static loads, which should be calculated according to Equation (1). This coefficient is basically a function of the theoretical span $(I=25 \mathrm{~m})$ between the supports in the longitudinal direction. These simplified assumptions were used in the computational analysis even knowing that overly simplified models of vehicles do not represent accurately the reality, especially if in a dynamic analysis the imperfections of the railway and the train wheels are not considered [14]

$$
\varphi=0.001 \cdot[1,600-(60 \cdot \sqrt{l})+(2.25 \cdot l)]=1.356
$$

\subsubsection{Horizontal actions}

The cross wind action was considered through a torsion moment (M) per unit length applied along the bridge, in the decks gravity center, as shown in Figure 6. For the determination of this loading, it was considered the action of wind (pressure of $0.98 \mathrm{kN} / \mathrm{m}^{2}$ with the loaded bridge) from the base of the stringer to the top of the wagon, with a total height of $7.3 \mathrm{~m}$., allowing the determination of $Q$ force per unit length. To consider the effect of the force caused by braking or acceleration of the train-type on the structure was adopted only a fraction of the live load in the longitudinal direction, without considering the impact coefficient, applied on top of the rails. The NBR 7187 [13] recommends the greater of the following: $15 \%$ of the live load for braking or $25 \%$ of the weight of the axles for acceleration. In the original bridge calculation memory braking force was only considered in the abutment and dispensed in the rest of the superstructure, and the same was done in the computational model. The values adopted for this action were 7,349 $\mathrm{kN}, 9,044 \mathrm{kN}$ and $75 \mathrm{kN}$ for the operating loaded train-type, future loaded and unloaded, respectively.

Also according to the NBR 7187 [13], the side impact wheel can be treated as a horizontal force perpendicular to the train-type, with a characteristic value of $20 \%$ of the load of the most loaded axle.

\section{Figure 6 - Wind action consideration}

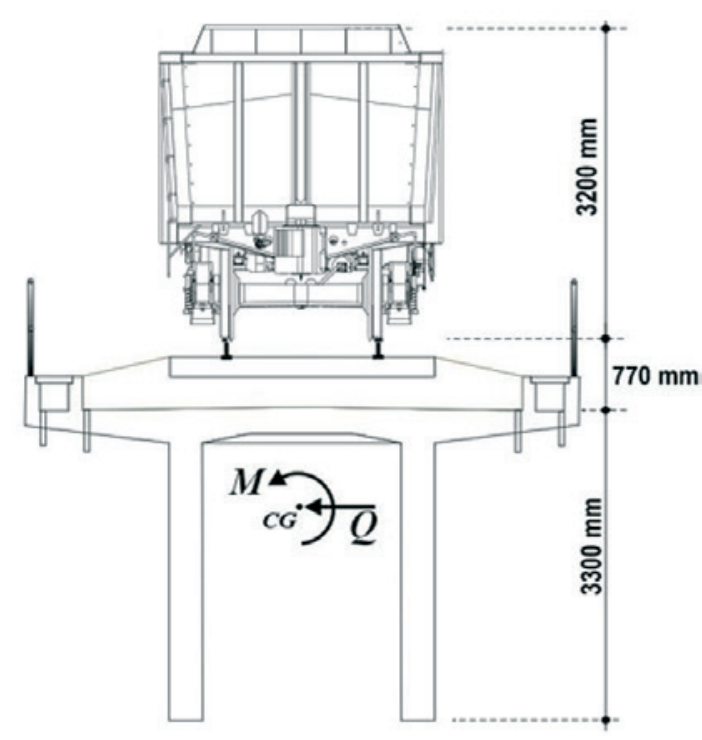




\section{Figure 7 - Finite elements model}
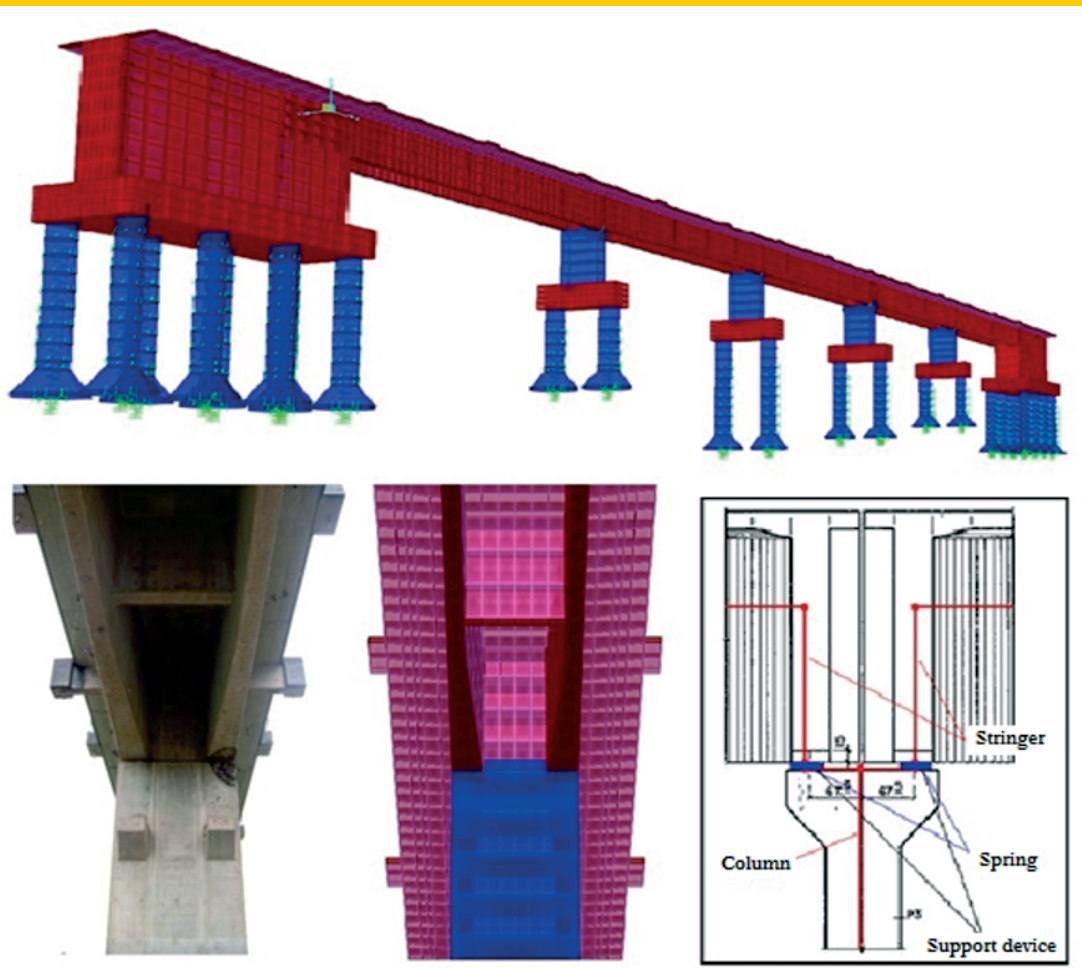

This procedure was also used in the design calculation memory. The values of this force were $65 \mathrm{kN}, 80 \mathrm{kN}$ and $60 \mathrm{kN}$ for the operating loaded train-type, future loaded and unloaded, respectively. Already the effects of shrinkage and temperature were supposed considering only the shortening of the material. According to NBR 6118 [11], it is possible to adopt the value $10^{-5} /{ }^{\circ} \mathrm{C}$ for the coefficient of thermal expansion of the concrete. For retraction in current elements of reinforced concrete, the above requirement recommends to adopt a corresponding deformation variation of the temperature of $15{ }^{\circ} \mathrm{C}$. The standard also recommends a $10{ }^{\circ} \mathrm{C}$ temperature range at $15{ }^{\circ} \mathrm{C}$ for elements with the smallest dimension of less than $500 \mathrm{~mm}$ to represent the only effect of thermal expansion or shortening. It was adopted then a $25^{\circ} \mathrm{C}$ temperature range to con-

\section{Table 4 - Support device's stiffness}

\begin{tabular}{|cc|}
\hline Stifiness & Value $(\mathrm{kN} / \mathrm{m})$ \\
\hline Axial $(\mathrm{z})$ & $26,160,000$ \\
\hline Shear $(x)$ & 15,630 \\
\hline Shear $(y)$ & 15,630 \\
\hline Rotation $(z-z)$ & 125 \\
\hline Rotation $(x-x)$ & 71,530 \\
Rotation $(y-y)$ & 209,300 \\
\hline
\end{tabular}

sider the effects of shrinkage and temperature on the structure. The equivalent horizontal forces, located on the top of each column can be estimated by the product of these parameters, i.e. the thermal expansion coefficient, temperature variation, the length of the structural element and the average stiffness of the support (column). The computer program data input requires only that be provided the temperature variation, since the properties of other structural elements are computed automatically by the geometry and properties of the materials that compose them.

\subsection{Boundary conditions}

In the computational model the elastomeric bearings were added in compliance with the design info, assuming that the columns and abutments are supported by blocks over caissons as shown in Figure 7. Its structural behavior was simulated using rigid beam elements (with semi-infinite stiffness) and five spring elements simulating the steel reinforced elastomeric pads on the top of the columns P1, P2, P3 and P4. Table 4 presents the translation and rotation stiffness of the elastomeric bearings calculated based on the recommendations presented by Pfeil [15]. The transversal coefficient of elasticity of the neoprene was $0.1 \mathrm{kN} / \mathrm{cm}^{2}$ and Poisson's ratio $(u)$ of 0.5 .

Additionally, springs were interchangeably inserted at each $1.0 \mathrm{~m}$ along the caisson shafts with depth according to the construction project, aiming to simulate the soil-structure interaction and thus the foundations behavior. To determine the soil stiffness coefficient 


\section{Table 5 - Concrete's parameters from the calculation memory}

\begin{tabular}{cc|} 
Parameter & Value \\
Characteristic strength & $18.0 \mathrm{MPa}$ \\
Elasticity modulus & $27.5 \mathrm{GPa}$ \\
Density & $24.5 \mathrm{kN} / \mathrm{m}^{3}$ \\
\hline
\end{tabular}

results from Standard Penetration Test (SPT) were analyzed and applied in the computational models. The soil reaction modulus is not only a property related to the ground, but also depends on the characteristics of the foundation and varies with its depth (even for a "homogeneous" layer) and with the loading distribution. It can be obtained through typical procedures, such as: a) experimental methods, b) calibration with rigorous numerical solutions and c) simplified theoretical models.

\subsection{Concrete's properties}

In the computational model the compressive strength of concrete $\left(f_{c k}\right)$ was admitted as $18 \mathrm{MPa}$ which was the value adopted in the original design. The value of the modulus of elasticity of the concrete used in this model was determined from Equation (2), recommended by previous version of NBR 6118 [11] and used in the original design of the structure in 1986. Table 5 presents the material properties adopted in the computational model.

$$
E_{c i}=5,940 \cdot \sqrt{\left(f_{c k}+3.5 \mathrm{MPa}\right)}=27.5 \mathrm{GPa}
$$

\section{Preliminary results}

\subsection{Cross sections design resistance}

To determine the flexural and shear strengths of the cross sections, an auxiliary computational routine was developed. In this routine the cross section is discretized into sections considering rebars to check serviceability limit states and ultimate limit strength. In these calculations the concrete and steel constitutive models were assumed according to NBR 6118 [11]. Figure 8 presents envelops of the design moments for the different load cases and the flexural strength of the bridge's stringers. Envelops of the design bending moments were obtained for these load cases: Vehicle 01 represents the case of the actual loaded train, assumed as $325 \mathrm{kN} /$ axis; Vehicle 02 represents the case of the actual unloaded train, assumed as $52.5 \mathrm{kN} / \mathrm{axis}$; Vehicle 03 represents the future loaded train, assumed as $400 \mathrm{kN} / a x i s$. In Figure 8, Vehicle 04 (max) and (min) presents the flexural strength of the stringers as a function of the negative and positive reinforcements. The flexural strength of the stringers varies along its length due to variations in the rebars detailing. Figure 8 shows that the flexural strength of the stringers is higher than the design bending moments caused by the actual and future loadings. Figure 9 presents envelops of the design shear forces for loads cases of Vehicles 01 to 03 . It also shows the shear strength of the stringers (Vehicle 04) considering that their widths vary along the spans. Once again it is possible to see that the shear strength is higher than the design shear force for the different load cases.

\subsection{Fatigue lifetime}

To determine the fatigue service life of the stringers, it was initially considered the variation of the bending moments due to the passage of loaded and unloaded current trains and loaded future trains, according to Table 3 . From the variation of the bending moments is possible to determine strains from stresses at any point of

Figure 8 - Bending moment envelopes on the stringer

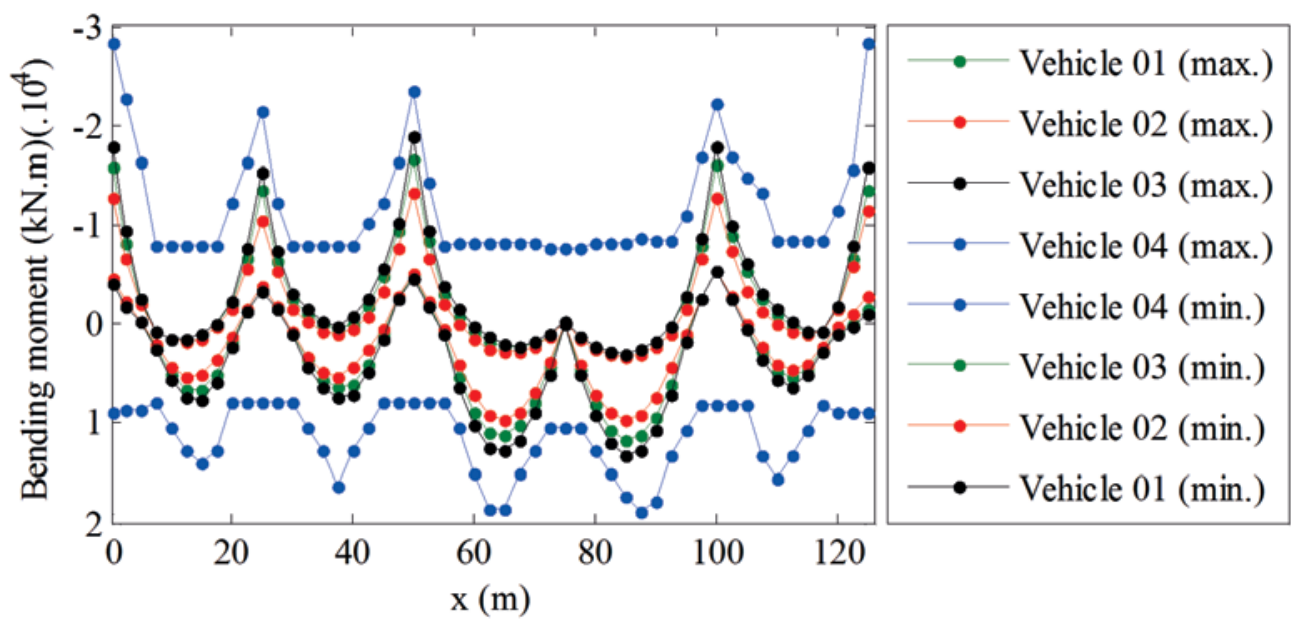




\section{Figure 9 - Shear forces on the stringer}

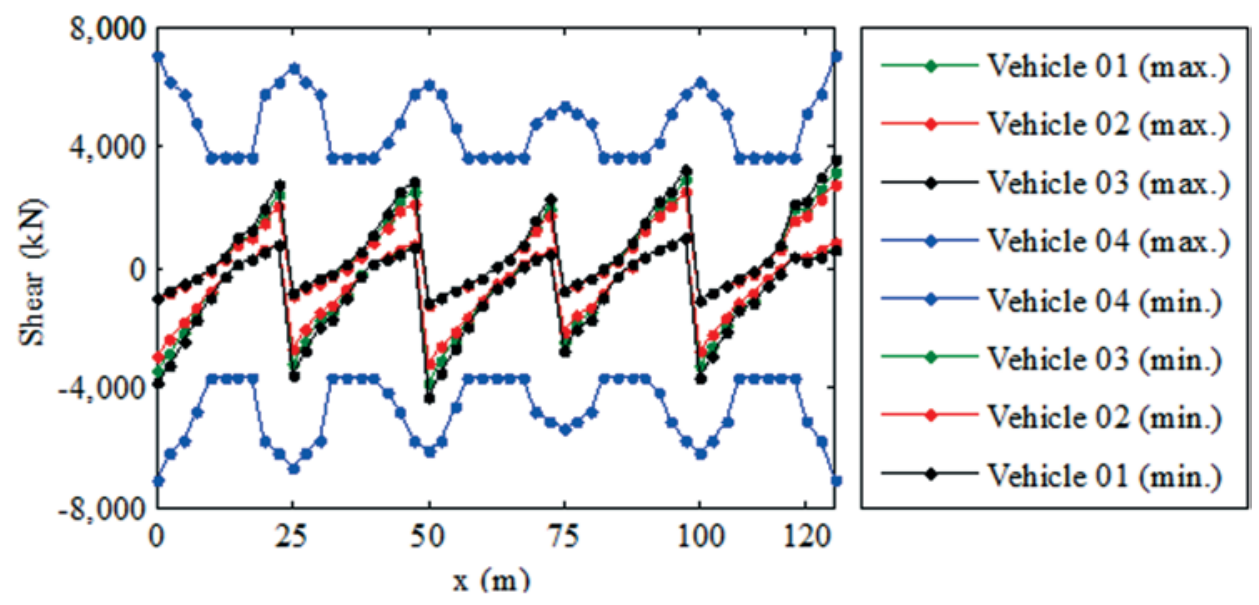

the stringers cross section. According to NBR 6118 [11] and EC2 [12] it should be determined the maximum and minimum stresses in an area not exceeding $300 \mathrm{~mm}$ from the edges of the cross section. Figure 10 shows the theoretical compressive stresses in the concrete and the theoretical tensile stress in longitudinal reinforcement of the section near the support (most loaded), due to the passage of the current loaded train. For a preliminary fatigue analysis the criteria presented by NBR 6118 [11] was used. According to this code, the verification of the fatigue of concrete is ensured if the maximum compressive stress in the concrete (corrected in function of the gradient of compressive stresses) do not exceed a stress fatigue limit of $45 \%$ of $f_{c d}=f_{c k} / 1.4$. This check is shown in Figure 11 , where the corrected stress is presented in module (with the positive sign indicating compression, in this case). The fatigue limit stress was then calculated at 5.8 MPa. Thus, according to NBR 6118 [11], only the stresses arising from the permanent load would already be very close to this limit, at the most loaded cross section. It should be noted that this criteria is quite conservative once actually does not consider the stress variations and, according to
Leander et al. [16], stress ranges when calculated with simplified methods, regular loads and distribution factors tend to result in a reduced remaining fatigue service life.

As already mentioned, it should be noted the fact that the verification of this limit state of fatigue NBR 6118 [11] is based on the ultimate limit state of fatigue of EC2 [12], which sequentially presents three methods for design verification, with increasing levels of refinement and precision. Unfortunately, for the verification of the concrete fatigue state, NBR 6118 [11] presents only the most simple and therefore more conservative prescription. On the other hand, EC2 [12] recommends the simplified method only as a preliminary analysis if the other two more refined methods are not used. Thus, for this reason, although fatigue criterion NBR 6118 [11] is not met for the section in question, shall be perform a more refined proceeding according to EC2 [12], and the results of this analysis are presented below. To use this more refined method, EC2 [12] suggests to use the Rain Flow Algorithm for cycles counting. Using this algorithm a count of cycles of stress in both the concrete and the steel (reinforcement) is possible, and using the fa-

Figure 10 - Theoretical stresses near the support
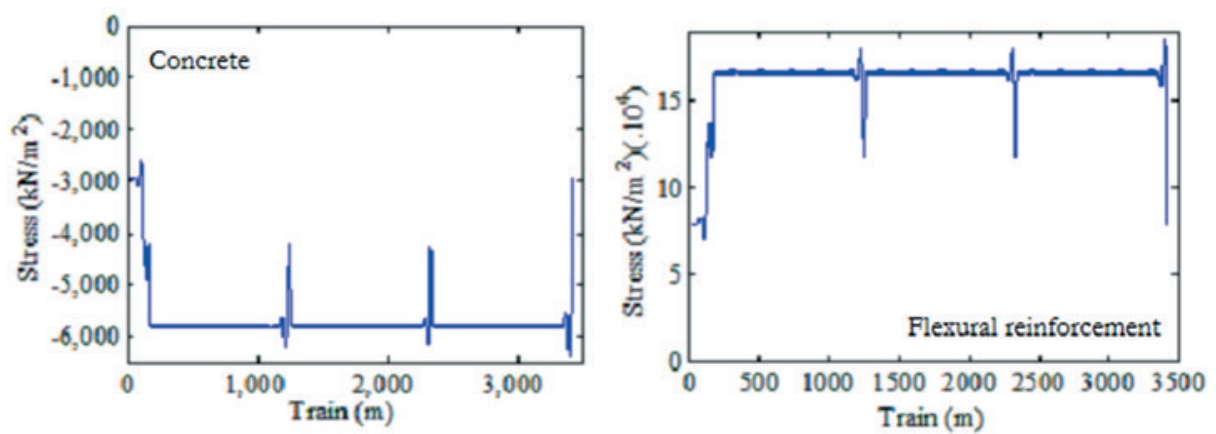


\section{Figure 11 - Limit fatigue stress according to NBR 6118}

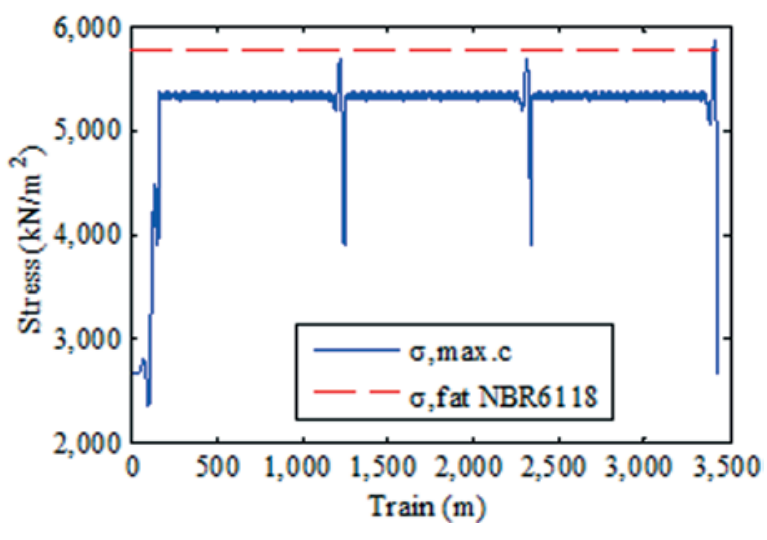

served that for the stringers the results for shear forces and bending moments (Figure 12) due to the dead loading were in good proximity to the calculation memory. In these figures the bridge was divided into 51 sections along the horizontal axis. When the effects caused by the passage of the train-type are taken into account can be observed in column P2 the highest value of axial force, with strong convergence between the results of the calculating memory (Vehicle 02) and computational model (Vehicle 01 loaded) for the maximum envelope, as illustrated in Figure 13. The trains' live loads considered in this analysis refer to the cases of the actual train live load and also for the future train live load for cases in which the train is loaded (Vehicle 03) and unloaded (Vehicle 04). Further, these results were compared with the live load considered in the original bridge design, in which the loaded train-type considered was Cooper E80 (Vehicle 05).

Like the work of Ermopoulos and Spyrakos [17] to verify the accuracy of the results obtained from the three-dimensional finite element model, the analytically estimated characteristic results were compared with the experimental ones. In the analytical procedure

Figure 12 - Shear forces and bending moments due to dead loads

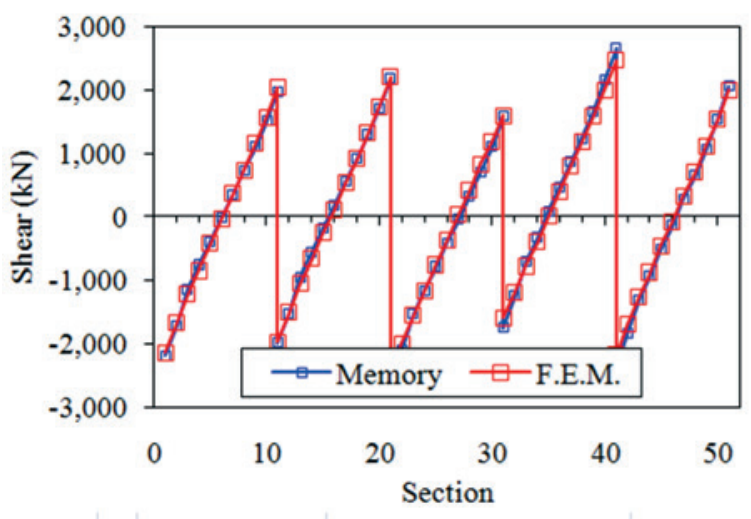

tigue strength functions and S-N curves to find the resisting stress cycles for these materials the fatigue analysis can be carried out. Therefore, for a more accurate result the principle stress strain relationship must be considered. The fatigue lifetime is the inverse of the maximum damage and is expressed in pairs of trains (loading blocks) and in years, considering the passage of 18 trains per day. The lifetime for the current train load is slightly higher than that for the future load. It is noteworthy that these lifetimes were estimated using the characteristic strength of concrete specified in the project, 18.0 MPa, for both operational and future trains. The other sections were also analyzed for fatigue and the results related to lifetime indicated that there is no risk of structural failure by materials fatigue, excepting a more rigorous analysis.

\section{Results comparison}

Initially, to prove the convergence of the final model using the finite element method (FEM), the computational results were compared to the original calculation memory results found in 1986. It was ob-

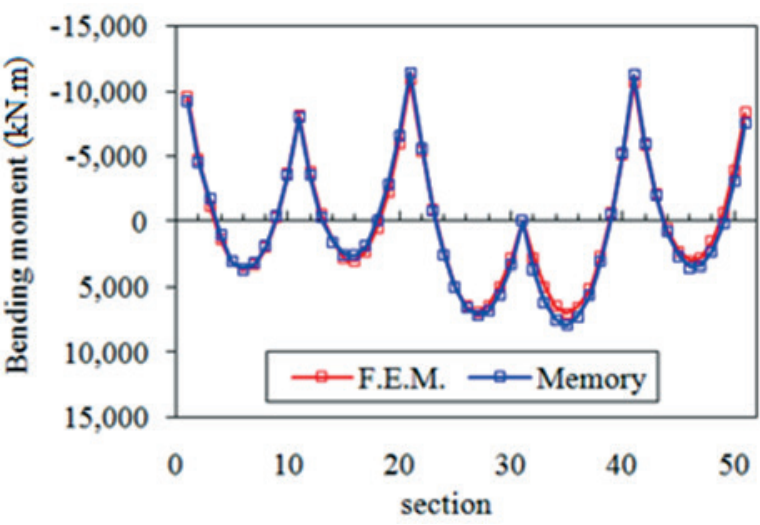

\section{Figure 13 - Reactions on column P2 due to live loads}

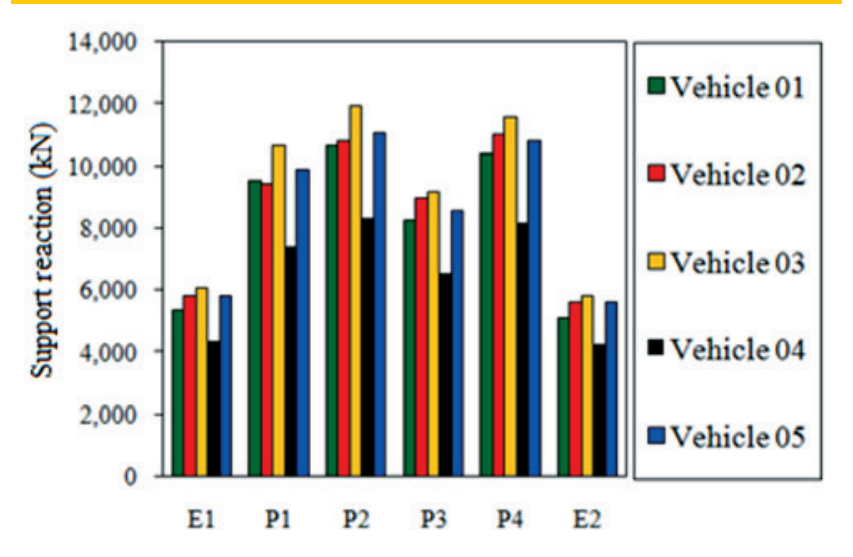




\section{Figure 14 - Historic of strains at the stringers' mid span (P1-P2)}

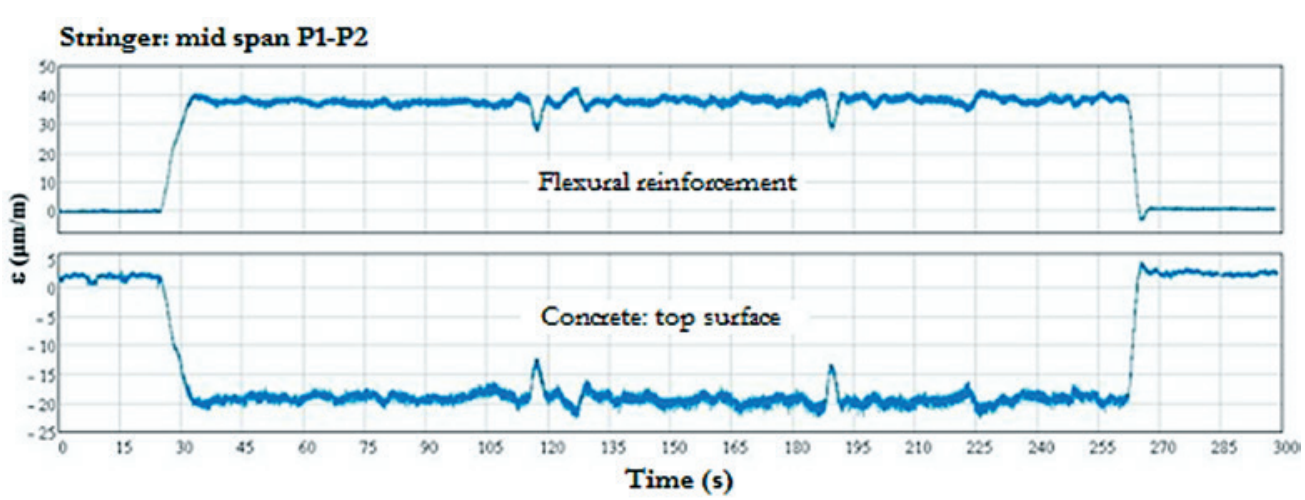

strains were calculated on the same sections monitored with strain gauges. A small part of the strain history at a point instrumented is presented. In this instrumented point two strain histories are shown, one is that obtained in situ from the strain gauges installed on the stringers concrete surface and the other signal refers to strains from theoretical influence lines provided by the program SAP $2000^{\circledR}$ with the vehicles passages, from which the historical record of internal forces and strains were determined. Figure 14 shows the computational response (left side) and the strain gauge experimental sign on concrete surface for comparisons, both related to the operational loaded train at the middle span cross section of the stringer between columns $\mathrm{P} 1$ and $\mathrm{P} 2$. Although the peaks observed in the computational response, caused by the passage of the two front locomotives on the previous (first peak) and next span, and not detectable by the strain gauge probably due to cracks on the upper concrete surface near the sensor, even so the results were close for the wagons' passage.

\section{Conclusions}

Considering the design envelopes for live and dead loads, it can be concluded that increases in structural strain occur when comparing the results for the current operational and future trains, both loaded, and that such loadings are less than the design resistance for all stringers' cross sections. Regarding the fatigue lifetime, the estimated results considering the design compressive strength (18.0 MPa) allow to state that the structure is safe for both trains, but further analysis must be done taking into account shear strength, stress combination of bending and shearing, cracking and creep effects, for example. The average experimental results from axial compression and elastic modulus tests on concrete were higher than those used in the structural design. Finally, the methodology applied to analyze the overall structural behavior was satisfactory in an absence of a nonlinear computational analysis considering the existing damages.

\section{Acknowledgments}

The authors acknowledge the financial support of FAPESPA, VALE, CAPES, CNPq and IPEAM at all stages of this work.

\section{References}

[01] Araujo, M. C.; Cai, S. C. S.; Teixeira, P. W. G. N.; Neiva, V. M. Transversal loadings distribution in precast concrete bridges - evaluation of the transversal beams influence using the NBR 6118:2003 prescriptions, LaDOTD and solid finite element models. 1st National Encounter of Research Design and Production in Concrete, Sao Carlos, UFSCar., Sao Carlos, CD-Rom, 2005. (in Portuguese)

[02] Orcesi, A. D.; Frangopol, D. M.; Kim, S. Optimization of a bridge maintenance strategies based on multiple limit states and monitoring. Engineering Structures, 32(3), 627-640, 2009.

[03] Furuta, H. Bridge reliability experiences in Japan. Engineering Structures, 20(11), 972-978, 1998.

[04] Canovas, M.F. Pathology and therapy of reinforced concrete. Pini, São Paulo, 1988. (in Portuguese)

[05] Cascudo, O. The control of corrosion of reinforcement in concrete: electrochemical and inspection techniques. Pini, São Paulo, 1997. (in Portuguese)

[06] Brazilian Association of technical Standards. NBR 7584 Hardened concrete: evaluation of surface hardness by rebound hammer reflection - test method. Brazilian Association of technical Standards, Rio de Janeiro, 2012. (in Portuguese)

[07] American Society for Testing and Materials. ASTM C42 - Test method for obtaining and testing drilled cores and sawed beams of concrete. American Society for Testing and Materials, United States, 1991.

[08] Brazilian Association of technical Standards. NBR 8522 Concrete: Determination of the elasticity modulus by compression. Brazilian Association of technical Standards, Rio de Janeiro, 2008. (in Portuguese)

[09] Malhotra, V. M. In situ/Nondestructive testing of concrete. American Concrete Institute, Detroit, 1984.

[10] Brazilian Association of technical Standards. NBR 5739 Concrete: Compression test of cylindrical specimens - method of test. Brazilian Association of technical Standards, Rio de Janeiro, 2007. (in Portuguese)

[11] Brazilian Association of technical Standards. NBR 6118 - Design of concrete structures. Brazilian Association of 
technical Standards, Rio de Janeiro, 2014. (in Portuguese)

[12] European Committee for Standardization. Eurocode 2 - Design of Concrete Structures. Part 1-1: General Rules and Rules for Buildings. European Committee for Standardization, Brussels, Belgium, 2004.

[13] Brazilian Association of technical Standards. NBR 7187 Reinforced and prestressed concrete bridges - procedure. Brazilian Association of technical Standards, Rio de Janeiro, 2003. (in Portuguese)

[14] Cai, S. C. S.; Deng, L. Identification of parameters of vehicles moving on bridges. Engineering Structures, 31(10), 2474-2485, 2009.

[15] Pfeil, W. Reinforced Concrete Bridges, Technical and Scientific Books, Rio de Janeiro, 1985.

[16] Leander, J.; Andersson, A.; Karoumi, R. Monitoring and enhanced fatigue evaluation of a steel railway bridge. Engineering Structures, 32(3), 854-863, 2009.

[17] Ermopoulos, J; Spyrakos, C. C. Validated analysis and strengthening of a 19th century railway bridge. Engineering Structures, 28, 783-792, 2006. 